\title{
The impact of the European Union fiscal rules on economic growth
}

\author{
Vítor Castro $^{\mathrm{a}, \mathrm{b}, *}$ \\ ${ }^{a}$ Faculty of Economics, University of Coimbra, Av. Dias da Silva 165, \\ 3004-512 Coimbra, Portugal \\ ${ }^{\mathrm{b}}$ University of Warwick (UK) and NIPE (Portugal)
}

\begin{abstract}
This paper analyses whether Maastricht and Stability and Growth Pact fiscal rules have affected growth in the European Union negatively. A growth equation is specified for a group of 15 European Union countries (and 8 OECD countries) over the period 1970-2005 to analyse this issue. Panel estimations using fixed-effects, pooled mean group and systemGMM estimators show that the institutional changes that occurred in the European Union after 1992 were not harmful to growth. Moreover, results show that growth is slightly higher in the period in which the fulfilment of the $3 \%$ criteria for the deficit started to be officially assessed, i.e. after 1997.
\end{abstract}

Keywords: European Union; Economic Growth; Fiscal rules; Pooled mean group estimator. JEL classification: E62, H6, O47.

\footnotetext{
* Tel.: +351239790 526; fax: +351 239790514 .

E-mail address: vcastro@fe.uc.pt.
} 


\section{Introduction}

To create an Economic and Monetary Union (EMU) in Europe, the members of the European Union (EU) agreed to lose independence over both monetary policy and exchange rate. They also agreed that fiscal policy should be kept in the hands of national governments and that rules to avoid excessive deficits should be put in place. Those rules were considered necessary because governments' temptation to create budget deficits to absorb negative shocks in an EMU could lead to problems of sustainability of those deficits and to growing government debts. There could also be negative spillovers for other EU states, and price stability policy of the Central Bank could be undermined. In particular, a country that allows its debt-GDP ratio to increase continuously could force the EU interest rate upwards, which would increase the burden of government debts in the other countries and would force them to follow more restrictive fiscal polices to stabilize their debt-GDP ratios. This might also compel countries to pressure the European Central Bank (ECB) to relax its monetary stance, which could endanger the stability of prices in Europe. These considerations led to the definition in the Maastricht Treaty of numerical budgetary rules that countries have to satisfy in order to take part in EMU: the 3\% of GDP deficit rule and the 60\% of GDP debt rule. These same rules were later reinforced in the Stability and Growth Pact (SGP) for countries in EMU, in order to avoid the problems mentioned above.

Thirlwall (2000), Arestis et al. (2001), Warin (2005) and Wyplosz (2006), among others, have argued that, despite the justification for fiscal rules in an EMU without a centralised budget, EU fiscal rules may have undermined economic growth in Europe. They consider that those rules reduce the margin of manoeuvre of the member countries when facing asymmetric shocks and, as a result, they are not growth promoting. Despite these 
theoretical considerations, very few empirical contributions exist to sustain or refute the idea that EU fiscal rules can be harmful to growth. ${ }^{1}$

This paper contributes to this literature by evaluating empirically the impact of EU fiscal rules on economic growth. Some improvements relative to previous empirical works are implemented, to overcome some perceived limitations. In particular, we employ a proper growth equation and a different method of estimation (pooled mean group estimation). Moreover, we use a dummy variable for the period in which fiscal rules started to be officially assessed and develop a new indicator to test directly for the impact of the EU fiscal rules on growth. Finally, we also provide a cross-comparison between EU and non-EU countries. Contrary to the theoretical and the few empirical studies on this issue, the results presented in this paper do not support the contention that fiscal rules have damaged growth.

The remainder of this paper is organized as follows. Section 2 presents the literature on the EU fiscal rules. Section 3 specifies the econometric model and the estimation techniques. Section 4 presents the data followed by the estimation of the model and discussion of the empirical results. Finally, section 5 provides a conclusion with the main findings of this paper.

\section{Literature on the $\mathbf{E U}$ fiscal rules}

In the literature there are several studies that try to evaluate the effectiveness of the EU fiscal rules. Some simply raise doubts about the rules themselves and the way they were defined by the European authorities in the SGP. ${ }^{2}$ Others like Gali and Perotti (2003), Marinheiro (2004) and Artis and Onorante (2006) analyse the impact of those rules on the conduct of fiscal policy by national governments and their impact on public investment and

\footnotetext{
${ }^{1}$ Hein and Truger (2005), Savona and Viviani (2003) and Soukiazis and Castro (2003, 2005) are the most relevant of the few papers that try to analyse this issue empirically.

${ }^{2}$ See, for example, Thirlwall (2000) and Arestis et al. (2001).
} 
on economic growth. Their results indicate that the improvement of budgetary balances in Europe was the result of a higher economic growth rather than active policy adjustments. However, the effect of those adjustments on growth itself is not examined in those studies. ${ }^{3}$ Another current of thought emphasizes the need to boost economic performance as a condition for improving a country's budgetary position in the long run and, consequently, economic growth should receive precedence over a strict application of the fiscal rules. Here, two studies must be highlighted: Von Hagen (2003) and Fatás, et al. (2003). The first argues that countries should be encouraged to adopt more growth-friendly policies by restructuring their government tax and expenditure systems; the second shows that expenditure-driven fiscal consolidations are more favourable to growth than revenue-driven consolidations.

Despite these approaches, few empirical studies have intended to demonstrate how economic behaviour in Europe has been affected by Maastricht and SGP rules. One seminal empirical analysis is provided by Hein and Truger (2005). They examine the effects of EMU monetary and fiscal policies on growth and on convergence across the Euro-area and observe that, despite a significant nominal convergence, there was no real convergence in the Euroarea. They also show that EMU macroeconomic policy institutions (ECB policy stance and SGP rules) have restrictive effects on growth. However, their conclusion that EMU macroeconomic policy institutions have restrictive effects on growth seems too strong: they analyse the whole period 1981-2001 without distinguishing the periods before and after the institutional cooperation has become stronger and they use an ad hoc specification without taking into account the economic growth literature. Hence, their growth equation can be criticised for not including important variables.

\footnotetext{
${ }^{3}$ Balassone and Franco (2000), Gali and Perotti (2003), Blanchard and Giavazzi (2004), Verde (2004), Perée and Välilä (2005) and Välilä and Mehrotra (2005) also study the relation between EU fiscal policy rules and public investment. Unfortunately, these studies do not proceed to test the subsequent effect of public investment on EU economic growth.
} 
A more consistent analysis can be found in Savona and Viviani (2003) and Soukiazis and Castro (2005). Their approaches are closer to growth theory. Even in these cases, though, a more adequate specification could be used: physical and human capital and short-term dynamics could be included in the model, since both studies use annual data. Savona and Viviani (2003) find evidence of a negative effect of current public spending on output growth and a positive impact of public capital spending on growth. In the light of these results, they argue for the modification of the rules of the Pact. In particular, they state that the rules should exempt public investment from constraints, but that the automatic checks on current public spending should be maintained. However, like Hein and Truger (2005), Savona and Viviani (2003) do not analyse the pre-and post-Maastricht (or SGP) periods separately nor the direct impact of Maastricht criteria and SGP rules on growth. Soukiazis and Castro (2003, 2005) make that direct analysis and observe that the greater fiscal discipline after Maastricht was harmful to both growth of real output and convergence in per capita income in the EU. However, the evidence behind this conclusion is not strong enough because, although they find a lower rate of convergence in per capita output after Maastricht, their dummy for the period after Maastricht is not statistically significant. Moreover, they do not separately estimate the effects of the components of the deficit (current spending, public investment, tax revenues) on growth and they do not include human capital in their regressions. The inclusion of those variables would make their analysis more in line with growth theory.

Departing from the existing literature, this study intends to overcome their flaws and provide a clear empirical answer to the question of whether the Maastricht and SGP fiscal rules have affected economic growth in Europe. It also tries to contribute to the literature with some improvements relative to the previous empirical works on the impact of EU institutional changes on growth. First, in this study the econometric analysis is built around a proper growth specification, unlike existing approaches that rely on ad-hoc (growth) equations. 
Second, short-run dynamics of output are controlled for by using both short-run regressors in the growth equations for annual data and a five-year time spans analysis. As annual variations in output contain cyclical components, it is necessary to consider a specification that takes into account those short-run dynamics when we are using annual data.

Third, a recently developed estimator is implemented in this analysis: a pooled mean group estimator. As this estimator allows for heterogeneity not only in the intercepts but also in other coefficients, it provides more flexibility than a fixed effects estimator to estimate the growth equation.

Fourth, a time dummy for the period in which fiscal rules started to be officially assessed is now used, instead of only a dummy for the period after Maastricht. This dummy is useful to cover the period of effective enforcement of the fiscal rules. Additionally, an indicator to control for the constraints that result from the implementation of the fiscal rules is developed: the margin of manoeuvre indicator. This indicator tries to capture the impact of the restrictions over fiscal policy on growth. Finally, this study goes even further in the analysis and provides a comparison between the economic performances of the EU countries and a group of industrial non-EU countries.

\section{Specification of the growth equation and econometric techniques}

According to the works of Mankiw et al. (1992), Islam (1995) and Bassanini and Scarpetta (2001), the following policy-augmented growth equation can be derived from a constant-returns-to-scale Cobb-Douglas production function: ${ }^{4}$

\footnotetext{
${ }^{4}$ The standard constant-returns-to-scale Cobb-Douglas production function is defined as: $Y(t)=K(t)^{\alpha} H(t)^{\beta}[A(t) L(t)]^{1-\alpha-\beta}$, where the level of output at time $t,(Y(t))$, is a function of physical capital, $(K(t))$, human capital, $(H(t))$, labour, $(L(t))$ and the level of technological and economic efficiency, $(A(t))$. The partial elasticity of output with respect to physical and human capital are represented by $\alpha$ and $\beta$, respectively. See Castro (2007) for a detailed derivation of the policy-augmented equation from this production function.
} 


$$
\begin{aligned}
\Delta \ln y(t)= & a_{0}-\phi \ln y(t-1)+a_{1} \ln s_{k}(t)+a_{2} \ln h(t)-a_{3} \ln [n(t)+g+d]+a_{4} t \\
& +\sum_{j} a_{j+4} \ln X_{j}+b_{1} \Delta \ln s_{k}(t)+b_{2} \Delta \ln h(t)+b_{3} \Delta \ln [n(t)+g+d] \\
& +\sum_{j} b_{j+3} \Delta \ln X_{j}
\end{aligned}
$$

where, $y(t)$ is the level of output per capita in the period $t, s_{k}(t)$ is the investment rate in physical, $h(t)$ is the stock of human capital, $n(t)$ is the growth rate of labour, $g$ is the constant growth rate of technological progress, $d$ is the constant depreciation rate of both types of capital and $X_{j}(t)$ is a vector of variables affecting economic efficiency. Short-term dynamics are controlled for to capture the short-run components of the dependent variable. ${ }^{5}$

In this model the observed growth of GDP per capita is the result of the technological progress, the convergence process to each individual-specific steady-state and the shifts in the steady-state that may arise from changes in policy, institutions, investment rates and changes in population growth rate (Bassanini and Scarpetta, 2001).

Annual data are used to estimate the growth equation - in line with Cellini (1997) and Bassanini and Scarpetta (2001) - instead of averages over time (twenty or five-year time spans) as in Mankiw et al. (1992) and Islam (1995). Data with annual frequency are preferred because large time spans can involve the loss of important information. Moreover, according to Cellini (1997), the use of annual data produces more plausible values for the elasticity of output to the exogenous variables than the estimates from lower frequency regressions. As annual variations in output contain cyclical components, it is necessary to consider a specification that takes into account those short-run dynamics. A way of controlling for those business cycle fluctuations is by including first-differences of the determinants of growth as

\footnotetext{
${ }^{5}$ The speed of convergence to the steady-state $(\lambda)$ and the time to cover half way to convergence $(h w t c)$ can be derived from the convergence parameter $(\phi)$ as follows: $\lambda=-\ln (1-\phi)$ and $h w t c=\ln (0.5) / \ln (1-\phi)$.
} 
short-run regressors in the equations. ${ }^{6}$ As a result, the general form of the growth equation can be written as an error correction model:

$$
\begin{aligned}
\Delta \ln y_{i, t}= & -\phi\left[\ln y_{i, t-1}-\theta_{1} \ln s k_{i, t}-\theta_{2} \ln h_{i, t}+\theta_{3} \ln \left(n_{i, t}+g+d\right)-\theta_{4} t-\theta_{0, i}\right. \\
& \left.-\sum_{j=5}^{m} \theta_{j} \ln X_{i, t}^{j}\right]+b_{1} \Delta \ln s k_{i, t}+b_{2} \Delta \ln h_{i, t}+b_{3} \Delta \ln \left(n_{i, t}+g+d\right) \\
& +\sum_{j=4}^{m} b_{j} \Delta \ln X_{i, t}^{j}+\varepsilon_{i, t}
\end{aligned}
$$

where $\varepsilon$ symbolizes the error term and $\theta_{s}$ represents the long-run coefficients. As usual in growth literature, a value of 0.05 is assigned to the constant $g+d{ }^{7}$

The model will be estimated by using pooled cross-country time-series data for $15 \mathrm{EU}$ countries, controlling for country-specific effects. In some regressions 8 additional industrial (OECD) countries will be included for comparative purposes. Equation (1) will be the basis for these estimations and then long-run coefficients will be obtained as $\theta_{s}=a_{s} / \phi$.

Fixed effects are preferred to random effects because the population of the $15 \mathrm{EU}$ countries is entirely represented in the sample for the period under analysis. ${ }^{8}$ Moreover, the use of fixed effects will allow us to control for and capture the actual specific characteristics of each country in the sample. However, this may not be the best method to employ in this analysis. The fixed effects estimator allows intercepts to differ across countries while the other coefficients are constrained to be the same. Indeed, there is no reason to assume that the speed of convergence to the steady-state should be the same across countries (Bassanini and Scarpeta (2001)). Although there are reasons to believe in common long-run coefficients across EU countries - given they have access to common technologies and have intense trade

\footnotetext{
${ }^{6}$ Another way of controlling for those annual fluctuations on output is by using larger time spans. Despite the already mentioned loss of important information, a specification for a larger time span (five-years) will be considered later in this work with the aim of comparing results.

${ }^{7}$ See, for example, Mankiw et al. (1992) and Cellini (1997).

${ }^{8}$ For details, see Marinheiro (2004). Hausman tests (not reported here) also supported the fixed effects estimator.
} 
relations - short-run dynamics and the speed of convergence may not be the same across countries. In order to control for that case, a pooled mean group (PMG) estimator is employed in a second phase of this study. This estimator, developed by Pesaran, Shin and Smith (1999), allows the intercepts, speed of convergence, short run coefficients and error variances to differ across groups but imposes homogeneity on long long-run coefficients. Thus, with the PMG procedure, we are able to estimate directly the following error correction version of the growth equation: ${ }^{9}$

$$
\begin{aligned}
\Delta \ln y_{i, t}= & -\phi_{i}\left[\ln y_{i, t-1}-\theta_{1} \ln s k_{i, t}-\theta_{2} \ln h_{i, t}+\theta_{3} \ln \left(n_{i, t}+g+d\right)-\theta_{4} t-\theta_{0, i}\right. \\
& \left.-\sum_{j=5}^{m} \theta_{j} \ln X_{i, t}^{j}\right]+b_{1, i} \Delta \ln s k_{i, t}+b_{2, i} \Delta \ln h_{i, t}+b_{3, i} \Delta \ln \left(n_{i, t}+g+d\right) \\
& +\sum_{j=4}^{m} b_{j, i} \Delta \ln X_{i, t}^{j}+\varepsilon_{i, t}
\end{aligned}
$$

and the long-run homogeneity hypothesis permits the direct identification of the parameters that affect the steady-state path of output per capita $\left(\theta_{s}=a_{s, i} / \phi_{i}\right)$.

This method requires $T$ large enough such that we can estimate the model for each group separately. Therefore, when the data allows, this method will be used and its results compared to the results obtained with the dynamic fixed effects (DFE) estimator.

\section{Empirical work}

This section starts by describing the data and variables used in the estimation of the growth equation. Then, the empirical results obtained from both the dynamic fixed effects estimator and the pooled mean group estimator will be presented and analysed. In the final part of this section those results will be compared with the results from the estimation of a growth equation using data for five-year time intervals instead of annual intervals.

\footnotetext{
${ }^{9}$ Note that both this equation and equation (2) rely on the assumption that regressors are cointegrated.
} 


\subsection{Data and description of the variables}

Annual data used to estimate the growth equation were mainly collected from the OECD Statistical Compendium (2006) for 15 EU countries and 8 non-EU countries over the period 1970-2005. ${ }^{10}$ A description of the variables used in this study and respective sources can be found in Table 1. The dependent variable is simply defined as the growth rate of real GDP per capita $(\Delta \ln Y)$.

\section{[Insert Table 1 around here]}

Traditional economic growth literature considers that the rate of accumulation of physical capital, the accumulation of human capital and population growth are the most important factors in determining the level of real output per capita. ${ }^{11}$ Indeed, significant differences in the investment rate over time and across countries are seen as a source of crosscountry differences in output per capita. Studies on growth also assume that labour force skills and experience can represent a form of capital: human capital (Mankiw et al., 1992). The variables used to collect the effects of the physical and human capital are the ratio of real private fixed capital formation to real GDP $(\ln P r i v I)$ and the average number of years of schooling of the working-age population $(\ln H K)$, respectively. Population growth $(\ln P o p)$ is another important variable to be considered in the growth equation.

Bassanini and Scarpetta (2001) argue that some macroeconomic issues must also be considered in a growth analysis, namely the impact of fiscal policy, the benefits of having low and stable inflation and the benefits of exploiting comparative advantages of trade. According to their analysis, fiscal policy can affect output and growth in the medium-term and over the business cycle. Those effects may come from the composition of public expenditure and from the sources of financing. More than the overall deficit, it is the composition of public

\footnotetext{
${ }^{10}$ The 15 EU countries are: Austria, Belgium, Denmark, Finland, France, Germany, Greece, Ireland, Italy, Luxembourg, Netherlands, Portugal, Spain, Sweden, and the UK; The 8 non-EU countries are: Australia, Canada, Iceland, Japan, New Zealand, Norway, Switzerland, and the USA.

${ }^{11}$ See, for example, Barro (1991), Barro and Sala-i-Martin (1992), Mankiw et al. (1992) and Islam (1995).
} 
spending that is relevant for economic growth. Furthermore, negative effects on growth arise when government relies more on direct (or distortionary) taxes and when its expenditure focuses on unproductive activities. Hence, the impact of fiscal policy should be evaluated by looking at the components of both government revenue (direct and indirect taxes) and expenditure (consumption and public investment).

Bassanini and Scarpetta (2001) also maintain that low and stable inflation can have a positive effect on the level of capital accumulation and consequently on growth because investment decisions are usually made with a long-run perspective. In addition, higher volatility in inflation brings uncertainty which discourages firms from investing in some interesting projects. Finally, they argue that the potential gains from trade and exposure to external competition are additional issues that must be controlled for.

Besides the traditional determinants of economic growth described above, some qualitative variables are included in the equation to control for the period in which fiscal rules were imposed in Europe. Particular attention will be given to the results from those variables because they will allow us to see whether EU fiscal rules have affected growth in Europe and, if so, whether that impact has been positive or negative.

A dummy variable, similar to the one used by Soukiazis and Castro (2005), was built to control for the period after Maastricht in the EU. This dummy is named D92eu and is equal to 1 when we are observing an EU country for the period 1992-2005, and 0 over the period 1970-1991. It will take value 0 over the entire period 1970-2005 for the other OECD countries. An alternative dummy is built and used for the period in which the fulfilment of the $3 \%$ criteria for the deficit is to be officially assessed. This period started in 1997 with the assessment of the countries that would take part in EMU. ${ }^{12}$ This second dummy is called

\footnotetext{
${ }^{12}$ Before 1997 countries had just to make efforts to converge; there was no particular sanction if convergence criteria were not accomplished in a particular year between 1992 and 1996. In 1997, the sanction is not to take
} 
D97eu and assumes value 1 for EU countries in the period 1997-2005 and 0 otherwise. In practice, $D 97 e u$ can be seen as a dummy that will account for the impact of the SGP rules after they really came into effect.

Additionally, eight non-EU countries will be included in the sample. Both the EU and the non-EU countries are industrialised countries with similar characteristics, deep economic relations, access to common technologies and linked economic cycles, which means that they are more or less similarly affected by economic shocks. Therefore, the dummies (that take always value 0 for the non-EU countries) will, in this case, capture and reflect with more accuracy the particular effect of the EU fiscal rules on growth. Assuming that other factors will affect both groups in a similar way, the main differences will come from the specificities of the institutional changes in the EU. Considering that the fiscal rules established by the Maastricht Treaty and SGP are a very important specific characteristic of the EU economy during the period 1992-2005, then the coefficients on both dummies will allow us to conclude whether those rules have had a particular impact on the EU economic growth.

Finally, to control more directly for the effects of the main constraint imposed over the public deficit after 1992 - i.e. the limit of 3\% of GDP for the deficit - we develop what we call an indicator for the margin of manoeuvre of fiscal policy $(M g M)$. This indicator measures the (normalised) distance of the actual level of the government budget surplus to the $3 \%$ fiscal rule for the deficit imposed after Maastricht. The 3\% deficit rule is the basis to define this indicator. The deficit ruls is the rule to which the European authorities have given more importance. As this rule started to be imposed only after the Maastricht Treaty was signed, we assume that before 1992 there were no (formal) fiscal constraints over the fiscal policy of the EU members. Therefore, countries had complete margin of manoeuvre over their fiscal policy. This means that the index we developed $(M g M)$ should be equal to one in that period, not accomplish the $3 \%$ rule for the deficit. See Castro (2007), for further details on the criteria and fines. 
indicating full margin of manoeuvre. In the period after Maastricht, we may have a range between full and no (zero) margin of manoeuvre $(0 \leq M g M \leq 1)$. If there is a surplus in the period after Maastricht we also consider that the country has full margin of manoeuvre over its fiscal policy.

To identify the margin of manoeuvre after Maastricht when a country has a deficit, we compute the distance between the actual budget deficit and the 3\%-limit imposed by Maastricht and the SGP and divide it by 3 to normalize the indicator. This means that as the deficit increases the margin of manoeuvre is reduced. In the limit, it will be 0 when the deficit is $3 \%$ of the GDP or above, which means that the country will be forced by the European Commission to take action to correct it. Consequently, in such situation a country is not formally allowed to use fiscal policy to stimulate output. ${ }^{13}$

Therefore, the margin of manoeuvre indicator was included in the model to capture the impact of the restrictions over fiscal policy on growth. The expectation is that the greater is the margin of manoeuvre this period, the stronger will be economic growth in the next period, because countries with a good fiscal margin of manoeuvre can always boost the economy in "bad times". As Maastricht and SGP rules reduce the margin of manoeuvre of fiscal policy in most EU countries, this means that if the coefficient on this variable is significantly positive then it can be concluded that the impact of those rules on EU economic growth was negative.

In practice, the growth equations to be empirically estimated are equal to equations (2) or (3) - depending on which estimator is used - plus the term $\gamma d_{i, t}$, where $d_{i, t}$ represents one of those qualitative variables that control for the period in which EU fiscal rules were imposed in the EU: D92eu, D97eu or $M g M$.

\footnotetext{
${ }^{13}$ See Table 1 for more details on how this indicator is built.
} 


\subsection{Regressions and interpretation of the main results}

Based on the theoretical approach and variables discussed above, this paper proceeds with the empirical analysis to determine whether fiscal rules imposed in Europe in the period after Maastricht have had a significant effect on growth in the EU countries. First, we will present and analyse the results from the dynamic fixed effects (DFE) estimator and then the results from a pooled mean group (PMG) estimator.

Before proceeding to the estimation of the error correction models, using either the DFE estimator or the PMG estimator, it is convenient to analyse whether the regressors are $I(0)$ or $I(1)$, i.e. whether they are stationary or not. Pesaran, Shin and Smith (1999) show that the same algorithm can be used to compute the PMG estimators whether regressors are $I(0)$ or I(1), but their asymptotic distributions are slightly different. If the regressors are not stationary but are $I(1)$, then it is necessary that they are cointegrated (this means that the error term of the long-run equation is a stationary process for all countries); otherwise, we cannot guarantee that the estimators are consistent and asymptotically efficient. Thus, to make the cointegration analysis, we start by testing the order of integration of the regressors and then if they are $I(1)$ - cointegration tests are performed.

Panel unit root tests for each variable are presented in Table 2. Statistics were obtained by applying the Im, Pesaran and Shin (2003) unit root test. This test assumes that all series are non-stationary under the null hypothesis. Results provide evidence that most of the regressors can be considered non-stationary (or $I(1)$ ) at a significance level of 5\%: only SDInfl and $\ln$ Pop seem to be clearly stationary; the other regressors are either non-stationary or borderline, so we proceed treating them as non-stationary.

\section{[Insert Table 2 around here]}

Having concluded that series are essentially integrated of order 1, some cointegration tests were performed by using Pedroni (1999) tests. Pedroni's panel tests for cointegration are also reported in Table 2. Results show that 4 of the 7 tests reject the null hypothesis of no- 
cointegration (panel v, pp, ADF and group pp tests). Although not all tests reject the null hypothesis, the majority do. This fact provides some evidence of cointegration among the variables, which permits us to proceed with the estimation of the growth model presented above using either a DFE estimator or a PMG estimator in the context of an error correction mechanism.

The results from a dynamic panel data estimation controlling for fixed effects are presented in Table 3. The presence of any pattern of heteroscedasticity and autocorrelation is controlled for by using robust standard errors. Economic policy variables are lagged one period in all estimations in order to better identify their long-run impact on output and to account for the usual delays in reporting of economic data. The time trend was not included in these regressions because, when included, it was never statistically significant. Columns 1, 2 and 3 present results just for EU countries. In the remaining estimations the non-EU countries are included with the intention of doing a comparative analysis.

\section{[Insert Table 3 around here]}

Results for the traditional determinants of economic growth are as expected. The convergence coefficient is statistically significant in all regressions presented in Table 3. Estimations show that convergence in output per capita in the EU countries runs at an annual rate of about 3.5\%, which means that each year an economy's GDP covers about $3.5 \%$ of its distance from the steady state. ${ }^{14}$ This suggests that it takes about 19 years to reduce by half the differences in output per capita among EU countries. The coefficients on physical and human capital and population growth have the expected signs and are highly significant in almost all specifications. Thus, an increase in private investment and years of schooling and a decrease in population growth have a positive impact on output per capita in the long-run.

\footnotetext{
${ }^{14}$ Although rather low, this is a value that is in accordance with some seminal contributions to the empirical growth literature: see Barro (1991), Barro and Sala-i-Martin (1992), Mankiw et al. (1992), among others.
} 
However, only private investment has significant effects in the short-run. ${ }^{15}$ This result can be interpreted as a consequence of the fact that it usually takes more time to increase human capital and population than to increase physical capital. Therefore, the effects of an increase in human capital or in the population are only really evident after a reasonable period of time, i.e. they are only felt in the long-run. ${ }^{16}$

As expected, government investment $(\ln G o v I)$ has a positive and significant impact on real output per capita while government final consumption expenditure $(\ln G o v C)$ affects it negatively both in the long-run and in the short-run. These results support the view of EU authorities that cuts in current expenditures to control the deficit may have positive effects on output in the long-run, but they also enhance the relevance given by some authors to public investment (Savona and Viviani (2003), Blanchard and Giavazzi (2004) and Verde (2004)). In fact, EU authorities should take into account not only the importance of controlling excessive deficits but also the benefits of 'productive' public investment in the definition and application of the fiscal rules to countries in the EMU.

It was also expected that a shift from taxing factor incomes to taxing consumption would have positive growth effects, but this study does not identify those positive effects in the long-run. The long-run coefficient on the variable $\ln G o v T x$ is not statistically significant in any of the regressions. In the short-run they seem to have an effect contrary to the one expected, but it is not always statistically significant.

The variability of inflation (SdInfl) has a negative impact on output per capita only in the long-run, which is in accord with the findings of Bassanini and Scarpetta (2001). Inflation itself was also used as an alternative, but results were quite similar. ${ }^{17}$ As inflation shows a high correlation with the convergence variable and human capital, the variability of inflation

\footnotetext{
${ }^{15}$ See results on the short-run dynamics.

${ }^{16}$ In fact, investment in education is always a long-run investment.

${ }^{17}$ Results are not presented here, but are available upon request.
} 
is used instead. ${ }^{18}$ The results also suggest significant gains from trade and exposure to external competition in the long-run. The sign of the coefficient on $\ln X / M$ indicates that the higher the proportion of exports over imports the higher the output per capita.

However, the results of most interest in this analysis come from the dummy variables for the post-Maastricht period. In the first regression presented in Table 3, the dummy D92eu was used to control for the growth effects in the EU-15 in the period after Maastricht. The coefficient on this variable is not significant. A similar result was obtained by Soukiazis and Castro (2005) in their convergence analysis. This result may indicate that the institutional changes that took place in Europe after Maastricht were not harmful to output growth. Indeed, when we consider a dummy just for the period in which the fiscal rules started to be assessed $(\mathrm{D} 97 \mathrm{eu})$ it is even possible to conclude that growth of real GDP per capita is significantly higher than before: results show that after 1997 growth of real GDP per capita is, on average, about 0.5 percentage points higher than before. Therefore, these results give us some scope to conclude that economic growth in the EU was not negatively affected by those rules, contrary to what some authors argue. ${ }^{19}$

The third regression includes the indicator for the margin of manoeuvre lagged one period but results show an insignificant coefficient. Hence, our expectation that the reduction of the margin of manoeuvre could affect output is not verified. One interesting conclusion can be retrieved from this result: the reduction of the margin of manoeuvre of fiscal policy in the period after Maastricht did not have a negative impact on growth, meaning once again that fiscal rules were not as harmful to growth of real GDP per capita as one might imagine. The lack of significance for the coefficient associated to $M g M$ is, therefore, supporting the results obtained with $\mathrm{D} 92 \mathrm{eu}$.

\footnotetext{
${ }^{18}$ Theoretically, it makes more sense to use the variability of inflation than its level, because the variability of inflation affects much more the decisions of consumption and investment (and the economic growth) in the medium and long-term than its level.

${ }^{19}$ For example, Thirlwall (2000), Arestis et al. (2001), Warin (2005) and Wyplosz (2006), among others.
} 
Next, other OECD developed countries were included in the sample for the period 1972-2004. Column 4 of Table 3 presents the results for the whole period. The dummy D97eu remains significant. In this case, that means that growth of GDP per capita in EU was not only higher than before 1997 but, at the same time, higher than in the other non-EU countries. To separate the temporal effect from the cross-country effects, estimations were performed just for the period after Maastricht. In column 5, the results for the period after 1992 are reported. In this case, the dummy $\mathrm{D} 92 \mathrm{eu}$ is directly comparing the difference in growth between EU and non-EU countries. Results for the dummy do not show a significant difference in growth of GDP per capita: the estimated coefficient on the dummy is positive but insignificant. However, when we consider just the period after 1997, and D97eu is included instead, it is possible to observe a significantly higher growth in the group of the EU countries than in the other countries. In this case, a random effects estimator was used because the dummy D97eu was dropped in the fixed effects estimation due to lack of variability. In order to overcome that problem, an estimation for the period 1992-2004 was performed (column 7) using the dummy $D 97 e u$. The significance of the coefficients improves and the dummy remains highly significant. In fact, this is giving more support to the idea that growth in the EU countries in the period after 1997 was not negatively affected by the fiscal rules. Indeed, if we gather the results of columns 6 and 7, there is evidence that growth was not lower in the EU than in the other non-EU countries.

Results of the PMG estimations and some robustness analyses are presented in Table 4. Only long-run and dummy coefficients are reported, in order to save space and given their relevance for this study. Columns 1 to 3 show the results of the PMG estimations for the EU countries over the period 1972-2004. ${ }^{20}$ The results of some robustness checks are shown in the remaining part of the table.

\footnotetext{
${ }^{20}$ The author wishes to thank Ed Blackburne for providing the STATA code to perform the PMG estimations.
} 
In the fixed effects estimations it was considered that intercepts could differ across groups but the other coefficients were constrained to be the same. Although the fact that the EU countries have access to common technologies and deep economic relations may justify the presence of common long-run coefficients, the speed of convergence to the steady-state and the short-run dynamics may not be the same across countries. Indeed, each country can follow a different path to the steady-state. Hence, the PMG estimator developed by Pesaran, Shin and Smith (1999) seems to be a suitable instrument to control for these specificities.

This method improves the significance of most estimates and generates a higher convergence coefficient. These results are a consequence of the improvements made on the assumptions of the model and are in line with the examples presented by Pesaran, Shin and Smith (1999). Now results suggest that it takes about 10 years to reduce by half the differences in output per capita among EU countries. This result seems to be more adequate for industrial countries that have been increasing their efforts of integration over the last decades. Estimated coefficients on physical and human capital and population growth have the expected signs and remain highly significant. Evidence on fiscal variables is also consistent with the previous findings: there is evidence favouring both the positive impact of public investment and the negative effect of public consumption on GDP per capita; and, once again, the positive effect of shifting taxes from factor incomes to consumption is not evident in the data. Finally, results confirm the negative impact of inflation on output and the expected gains from trade.

The most relevant findings are provided by the time dummies and by the margin of manoeuvre indicator. The coefficient on the dummy for the period after Maastricht (D92eu) remains insignificant. Considering the dummy for the period in which the fiscal rules started to be officially assessed ( $\mathrm{D} 97 \mathrm{eu})$, we get evidence that supports the previous finding that real growth of GDP per capita was slightly higher during that period than before. In this case, results show that after 1997 growth of real GDP per capita is, on average, about 0.9 
percentage points higher than before. Finally, when the indicator for the margin of manoeuvre is included instead of the dummies, results confirm the insignificance of its coefficient, which, once again, supports de results given by $D 92 e u$. Thus, these results indicate that the restrictions over the deficit did not affect countries' capacity to use fiscal policy over the economic cycle. Therefore, the results from the PMG estimations reinforce our conclusion that economic growth was not negatively affected by the EU fiscal rules.

It is not possible to use the PMG estimator to compare EU and non-EU countries due to the lack of variability of the dummy variables when the model is estimated for each country separately before retrieving the PMG estimates. Moreover, PMG estimator requires a $T$ large enough such that we can estimate the model for each country individually. This means that it is not viable to proceed with a comparative analysis of our model for the periods before and after Maastricht either. ${ }^{21}$ Therefore, this study proceeds with the robustness analysis by using a fixed effects estimator. Results are presented in columns 4 to 7 of Table 4.

\section{[Insert Table 4 around here]}

Column 4 presents results of an identical specification to columns 6 of Table 3, but using a different estimation method, which is more suited to cases like this, where the number of time periods is substantially smaller than the number of individuals ( $\mathrm{T}$ small, $\mathrm{N}$ large). This specification is based on the application of Arellano and Bond's (1991) GMM estimator. ${ }^{22}$ This method improves the statistical significance of the coefficients and the results are, once again, indicating that after 1997 growth of GDP per capita in the EU countries is, on average,

\footnotetext{
${ }^{21}$ Due to the very low number of degrees of freedom it is not possible to get estimates for the convergence coefficient for some countries in the sample.

${ }^{22}$ In the regression of column 4, the log of real GDP per capita is instrumented with its second and following lags and the other variables are instrumented with their own values.
} 
higher than growth in other industrial OECD countries; when the threshold is 1992, no significant differences are found. ${ }^{23}$

In columns 5 and 6 , we compare the economic performance of the EU countries before and after 1997; the same is done for the periods before and after 1992, but only the convergence coefficient is reported. Instead of using dummies, a separate regression for each period is estimated. The focus of this analysis will be in comparing the convergence coefficient of each regression. The convergence coefficient for the period before 1997 is considerably lower (in absolute value) than the one for the period after 1997, meaning that the speed of convergence to the steady-state is higher in the period in which fiscal rules are officially enforced than before. This evidence confirms the result given by $d 97 e u$ above. When we compare pre-and post-Maastricht periods separately no substantial differences are found, confirming once again the results obtained before for the case where $d 92 e u$ was used.

The last column reports estimates to compare the performance of the non-EU countries with the performance of the EU countries in the period after 1997 (and 1992). Despite the problems of significance due to the low number of observations in the regression for non-EU countries, results show that the speed of convergence in the EU countries is not substantially different from the other OECD countries, whichever period is considered. This is further evidence to reinforce the idea that EU fiscal rules may have not indeed affected economic growth in Europe.

Thus, from this simple analysis it is possible to conclude that output growth was not negatively affected in the period after Maastricht in the EU. Therefore, Maastricht and SGP fiscal rules for the deficit and debt should not be blamed for being harmful to growth of real GDP per capita in the EU countries. On the contrary, evidence shows that, on average, growth is statistically higher in the period in which the fulfilment of the $3 \%$ criteria for the deficit

\footnotetext{
${ }^{23}$ In this case only the results for the convergence coefficient and the dummy are reported; the estimated coefficients for the other variables are available upon request.
} 
started to be officially assessed - either comparing it with the past performance of the EU countries or even with the performance of other developed countries.

Other estimations were performed including the level of inflation instead of its volatility, the deficit instead of the fiscal variables, the public debt and the average growth in the OECD countries, and even variables controlling for the iteration of the exogenous variables with the dummies, but the main results remain unchanged. The results on the fiscal variables do not change even when all economic policy variables are excluded from the model. Some attempts were made to improve the indicator for the margin of manoeuvre, but it remained insignificant. The results and conclusions of this work are also robust to the exclusion of one EU country at a time from the sample, to the exclusion of the 3 EU countries that did not take part in the EMU (Denmark, Sweden and UK) and remain valid even when only the group of countries that have had problems in accomplishing the $3 \%$ rule for the deficit is considered in the sample (France, Germany, Greece, Italy, Portugal and UK). A final analysis assessed whether growth was higher in the non-EU countries after 1997, like it was in the EU countries. Results shown that, on average, growth was not significantly higher in the other OECD countries after $1997 .^{24}$ This result gives more support to the idea advanced in this study that EU economic growth was not negatively affected by the fiscal rules.

\subsection{Estimations using five-year time intervals}

In the empirical analysis so far, annual data have been used to estimate the growth equation. Yearly time spans are used to avoid the loss of important information that might result from the use of larger time spans. The justification for the choice of annual data becomes more evident when economic performance of the EU and on-EU countries is compared and when a separate comparative analysis for the periods before and after

\footnotetext{
${ }^{24}$ Those estimation results are not reported here, but they are available in Castro (2007).
} 
Maastricht (or SGP) is made. This choice implied the inclusion of short-run dynamics in the equation to control for cyclical fluctuations of output.

Another way of avoiding the problem of the short-run business cycle fluctuations of output is precisely by using data from larger time intervals. Despite the mentioned loss of information that may result from the use of these larger time spans, we will proceed with the estimation of some growth equations using data from five-year time intervals in line with the works by Islam (1995), Caselli et al. (1996), Bond et al. (2001) and Ederveen et al. (2006). The objective of this analysis is to evaluate the robustness of the results to a change in the time spans.

As a result of the use of five-year time intervals, the general form of the growth equation can simply be written as:

$$
\Delta \ln y_{i, t}=\alpha_{0, i}+\phi \ln y_{i, t-1}+\beta_{1} \ln s k_{i, t}+\beta_{2} \ln h_{i, t}+\beta_{3} \ln \left(n_{i, t}+0.05\right)+x_{i, t}^{\prime} \delta+\gamma d_{i, t}+\varepsilon_{i, t}
$$

for $i=1, \ldots, N$ and $t=2, \ldots, T$, where $\Delta \ln y_{i, t}$ is the $\log$ difference in output per capita over a five-year period, $\ln y_{i, t-1}$ is the logarithm of output per capita at the start of that period and $x_{i, t}$ is a vector of additional variables to be included in the basic growth equation. These variables and the other explanatory variables $(\ln s k, \ln h, \ln (n+0.05))$ are measured as the average over each five-year period. A dummy or qualitative variable $\left(d_{i, t}\right)$ is added to the equation to control for the period in which EU fiscal rules were imposed in the EU.

Considering the same data and time period used in the annual analysis (1970-2005), seven five-year time spans are constructed for the $15 \mathrm{EU}$ countries. These data is then used in the estimation of equation (4). Different estimators have been used in the literature to estimate this kind of dynamic panel data models. In this analysis we will basically employ fixed effects (FE) and generalized method of moments (GMM) estimators. The results of the estimation of 
the growth equation considering five-year time spans are reported in Table 5. The regressions consider the same variables used in the annual analysis. ${ }^{25}$

\section{[Insert Table 5 around here]}

The estimates presented in column 1 and 2 were obtained by using a FE estimator. The convergence coefficient has the correct sign and is statistically significant in all of the estimations, showing that convergence in output per capita runs at an annual rate of about $8 \%$. The coefficients on physical and human capital and population growth have the expected signs and are significant. The additional variables do not present robust results: only the government consumption $(\ln G o v C)$ and the $\log$ of the ratio of exports over imports $(\ln X / M)$ have the expected signs and are significant; a shift from taxing factor incomes to taxing consumption has a negative effect on output, contrary to expectations; and the other variables are not significant. Moreover, neither of the dummies nor the margin of manoeuvre are significant, which can be interpreted as an additional empirical support to the idea advanced in this study that institutional changes that took place in Europe after Maastricht were not harmful to growth.

As the fixed effects estimator may lead to inconsistent estimates in the context of empirical growth models, results from GMM estimators are reported in columns 3, 4 and 5 . The instruments used for the first-differenced GMM estimator (DIF-GMM) are the second and third lags of the log of output per capita. All other right-hand-side variables are assumed exogenous and are instrumented with just their own values in order to avoid the problem of too many instruments. The additional instrument used in the system GMM estimator (SYSGMM) is the difference of the log of output per capita lagged one period. Moreover, the

\footnotetext{
${ }^{25}$ Note, however, that as we are considering five-year time intervals, it is not possible to use rigorously the same time periods for the dummies. The best we can do is to use a dummy that takes value 1 from the time interval 1991-1995 onwards (D9leu) and a dummy that takes value 1 in the intervals starting in 1996 and 2001 (D96eu).
} 
Hansen test of over-identifying restrictions does not rejects the overall validity of those instruments.

Results for the DIF-GMM estimator show a higher rate of convergence of output to its steady-state, but the physical capital variable is no longer significant and the coefficient on government investment has a sign contrary to the expected. As the sample contains a small number of time periods, these results can be the consequence of the finite sample bias of this estimator. To avoid that problem, we also report results from a system GMM estimator (SYSGMM), which tends to produce more reliable results in this kind of studies.

The SYS-GMM estimator reports a lower estimate for the speed of convergence than the DIF-GMM, but not very far from the one obtained by using a FE estimator. ${ }^{26}$ In general, the coefficients are not very different from the ones obtained by fixed effects. The main difference comes from the dummy for the period in which fiscal rules are officially assessed. In this case, we find evidence of a higher growth rate in that period than before. Results show that in the period after 1996 annual growth of real GDP per capita is, on average, about 0.86 percentage points higher than in the period before. In addition, no significant differences in growth are found in the pre- and post-Maastricht periods. ${ }^{27}$

As the coefficients associated with the additional explanatory variables are not significant, a simple basic growth model was considered in the regression presented in column 5. However, despite the evidence of a slightly slower speed of convergence, the main conclusions of this paper are not affected. As a final robustness check of the results obtained so far, column 6 reports the results obtained by a simple two-stages least squares estimator (2SLS), where the log of the initial output per capita is instrumented with its second lag. As the

\footnotetext{
${ }^{26}$ The SYS-GMM estimates indicate a speed of convergence of about $9 \%$. These estimates are very similar to the ones obtained with the PMG estimator for yearly-time spans. They are even close to the GMM estimates obtained by Caselli et al. (1996) and Ederveen et al. (2006).

${ }^{27}$ The margin of manoeuvre was also included in the GMM estimations (results are not reported here). However, as in the case of the FE estimations, its coefficient was never statistically significant.
} 
sample size is not large, reasonable results are expected from this estimator. Indeed, the main findings are not substantially different from the ones obtained with the other estimators.

In sum, the results obtained using five-year time spans corroborate the main conclusion of the yearly-time spans analysis: growth of real GDP per capita in the EU was not negatively affected in the period after Maastricht, i.e. in the period in which fiscal rules were imposed over the EU countries.

\section{Conclusions}

This paper intends to find an empirical answer to the question of whether the SGP fiscal rules have affected EU growth negatively. We start by showing that there is no consensus in the literature regarding this issue: some authors claim that the SGP fiscal rules can be prejudicial for growth in the EU; others argue that those rules are necessary to promote fiscal consolidation and economic stability in the EMU, which, in turn, will be beneficial for growth in the long-run. However, very little empirical work has been done to clarify this debate. The aim of this study is to contribute to this debate with solid empirical evidence. It also tries to introduce some improvements relative to previous empirical works in order to overcome their limitations. In particular, a proper growth equation and a different method of estimation (pooled mean group estimation) are employed. A dummy variable for the period in which fiscal rules started to be officially assessed is used and a new indicator - called margin of manoeuvre indicator - is developed and included in the model to be tested. Finally, we provide a cross-comparison between EU and non-EU countries.

Considering those improvements and using a specific growth equation for both yearly and five-year time spans, this paper shows that growth was not negatively affected in the period after Maastricht in the EU. This conclusion holds even when we compare recent performance of EU countries with their past performance or with the performance of other developed countries. Therefore, the evidence provided in this paper allows us to conclude that 
Maastricht and SGP fiscal rules were not harmful to growth of real GDP per capita in the group of $15 \mathrm{EU}$ countries analysed in this study. On the contrary, evidence shows that, on average, growth is statistically higher in the period in which the fulfilment of the $3 \%$ criteria for the deficit started to be officially assessed. This study also presents some evidence favouring the EU fiscal rules for the public deficit and debt.

In sum, all the relevant evidence provided by this study is against the claims that the SGP fiscal rules can be prejudicial for growth in the EU and sustains the view that those rules are important to promote fiscal consolidation and the necessary economic stability, which are essential to guarantee a sustainable economic growth in the long-run.

Evidence from the annual analysis also indicates that an increase in government investment has a positive and significant impact on real output per capita. Therefore, EU authorities should give some special attention to the potential benefits of productive public investment when assessing whether a deficit is excessive. Otherwise, some countries could find it easier to cut public investment than current expenditures in 'bad' times to accomplish the $3 \%$ deficit/GDP ratio. According to the findings of this study, such behaviour would be prejudicial for output growth.

Additionally, our results also suggest that it takes roughly a decade to reduce by half the differences in output per capita among EU countries and that an increase in private investment and years of schooling and a decrease in population growth have a positive impact on output per capita. These results are all in line with the economic growth literature.

An interesting extension to the analysis provided in this paper could be to make a similar analysis using the countries that have joined to the EU in this decade. The study of the impact of the fiscal constraints and institutional changes that they have to face to control their public accounts and to enhance the credibility of their institutions may possibly bring some additional insights to the understanding of the impact of those constraints on their economic 
performance. One obstacle to that study could be the lack of data for the decades of 1970s and 1980s for some of those countries.

Finally, once more data becomes available, another possible extension to this study could be to analyse how the EU countries have been coping with the reformed SGP and what have been its implications for economic growth. In particular, it would be interesting to analyse whether the reformed SGP has continued to promote the necessary balanced budgets in periods of economic expansion and whether it has been more flexible in allowing the required margin of manoeuvre for the EU countries to stimulate growth in periods of economic slowdown or recession. In other words, it would be worthwhile to analyse whether the reformed SGP has been more growth promoting while it tries to keep EU governments' accounts on the track of a balanced budget over the medium-term.

\section{Acknowledgments}

The author is in debt to Jennifer Smith for many fruitful discussions, comments, suggestions and revisions. The author also acknowledges Natalie Chen, Francisco Veiga, Elias Soukiazis, the participants at the INFER Workshop on 'Integration and Globalization' and the two referees of this paper for invaluable comments and suggestions. The author also wishes to express his gratitude for the financial support from the Portuguese Foundation for Science and Technology (FCT) under Scholarship SFRH/BD/21500/2005. 


\section{Bibliographical references}

Arellano, M., Bond, S. (1991) 'Some specification tests for panel data: Monte Carlo evidence and an application to employment equations'. Review of Economic Studies 58, 277-298.

Arestis, P., McCauley, K., Sawyer, M (2001) 'An alternative stability pact for the European Union'. Cambridge Journal of Economics 25, 113-130.

Artis, M., Onorante, L. (2006) 'The economic importance of fiscal rules'. CEPR Discussion Paper 5684.

Barro, R. (1991) 'Economic growth in a cross-section of countries'. Quarterly Journal of Economics 106, 407-443.

Barro, R., Sala-i-Martin, X (1992) 'Convergence'. Journal of Political Economy, 100, 223251.

Balassone, F., Franco, D. (2000) 'Public investment, the Stability and Growth Pact and the Golden Rule'. Fiscal Studies, 21, 207-299.

Bassanini, A., Scarpetta, S. (2001) 'The driving forces of economic growth: panel data evidence for the OECD countries'. OECD Economic Studies, 33(II), 9-56.

Blanchard, O., Giavazzi, F. (2004) 'Improving the SGP through a proper accounting of public investment'. CEPR Discussion Paper No. 4220.

Bond, S., Hoeffler, A., Temple, J. (2001) 'GMM estimation of empirical growth models'. Mimeo, available at «http://staff.feweb.vu.nl/celbers/GMMgrowthreg.pdf».

Caselli, F., Esquivel, G., Lefort, F. (1996) 'Reopening the convergence debate: a new look at cross-country growth empirics'. Journal of Economic Growth 1, 363-389.

Castro, V., 2007 'The impact of the European Union fiscal rules on economic growth'. The Warwick Economics Research Paper Series (TWERPS), Working Paper No. 794, available at «http://www2.warwick.ac.uk/fac/soc/economics/research/papers/».

Cellini, R (1997) 'Growth empirics: evidence from a panel of annual data'. Applied Economic Letters 4, 347-351. 
De la Fuente, A., Doménech, R. (2000) 'Human capital in growth regressions: how much difference does data quality make?' Universidad Autónoma de Barcelona, Mimeo, available at «http://ideas.repec.org/aub/autbar/446.00.html»

Ederveen, S., Groot, H., Nahuis, R. (2006) 'Fertile soil for structural funds? A panel data analysis of the conditional effectiveness of European cohesion policy'. Kyklos 59, 17-42.

Fatás, A., von Hagen, J., Hughes-Hallett, A. Strauch, R., Sibert, A. (2003) 'Stability and Growth in Europe: towards a better Pact'. CEPR, Monitoring European Integration 13.

Gali, J., Perotti, R. (2003) 'Fiscal policy and monetary integration in Europe'. NBER Working Paper No. 9773.

Hein, E., Truger, A. (2005) 'European Monetary Union: nominal convergence, real divergence and slow growth?' Structural Change and Economic Dynamics 16, 7-33.

Islam, N. (1995) 'Growth empirics: a panel data approach'. Quarterly Journal of Economics $110,1127-1170$.

Mankiw, G., Romer, D., Weil, D. (1992) 'A contribution to the empirics of economic growth'. Quarterly Journal of Eonomics 107, 407-437.

Marinheiro, C. (2004) 'Has the Stability and Growth Pact stabilized?' Mimeo, available at «http://www4.fe.uc.pt/carlosm/research/pdf/sgpdec04_cmarinheiro.pdf».

OECD (1998-2006), Education at a Glance, various issues.

OECD (2006). Statistical Compendium, April 2006.

Pedroni, P. (1999). 'Critical values for cointegration tests in heterogeneous panels with multiple regressors'. Oxford Bulletin of Economics and Statistics 61, 653-670.

Perée, E., Välilä, T. (2005) 'Fiscal rules and public investment'. European Investment Bank Economic and Financial Report 2005/02.

Pesaran, M., Shin, Y., Smith, R. (1999) 'Pooled mean estimation of dynamic heterogeneous panels'. Journal of American Statistical Association 94, 621-634. 
Savona, P., Viviani, C. (2003) 'The impact of the Stability and growth pact on real economic growth: automatic mechanism or policy discretion?' Review of Economic Conditions in Italy 2, 263-279.

Soukiazis, E., Castro, V. (2003) 'The impact of the Maastricht criteria and the Stability and Growth Pact on growth and unemployment in Europe'. CEUNEUROP, Discussion Paper No. 15, available at «http://www4.fe.uc.pt/ceue».

Soukiazis, E., Castro, V. (2005) 'How the Maastricht criteria and the Stability and Growth Pact affected real convergence in the European Union: a panel data analysis'. Journal of Policy Modeling 27, 385-399.

Thirlwall, A., (2000) 'The Euro and regional divergence in Europe'. Mimeo, available at «http://www.kent.ac.uk/economics/staff/at4/curres.html».

Välilä, T., Mehrotra, A. (2005) 'Evolution and determinants of public investment in Europe'. European Investment Bank Economic and Financial Report 2005/01.

Verde, A. (2004) 'The Stability and Growth Pact in rainy days: an alternative view'. Bank of Valletta Review 30, 14-31.

Von Hagen, J. (2003) 'Fiscal discipline and growth in Euroland: experiences with the Stability and Growth Pact'. Centre for European Integration Studies (ZEI) Working Paper B-06-2003. University of Bonn.

Warin, T. (2005) 'The hidden structural features of the fiscal rule: a European saga'. International Advances in Economic Research 11, 29-38.

Wyplosz, C. (2006) 'European Monetary Union: the dark sides of a major success'. Economic Policy 21, 207-261. 


\section{Tables}

Table 1. Description of the Variables

\section{Dependent variable:}

$\Delta \ln Y$ - growth rate of real GDP per capita of population aged 15-64 years old at price levels and purchasing power parities (PPP) of 2000.

\section{Convergence variable:}

$\ln Y_{t-1}$ - lagged real GDP per capita of population aged 15-64 years at price levels and PPP of 2000.

\section{Basic economic growth explanatory variables:}

$\ln$ PrivI - the logarithm of the ratio of the real private fixed capital formation to real GDP is used as a proxy for the propensity to accumulate physical capital.

$\ln H K$ - the stock of human capital is proxied by the logarithm of the average number of years of schooling of the (working-age) population from 25 to 64 years of age.

$\ln$ Pop - represents the log of population (aged 15-64) growth (i.e. $n$ ) plus the constant $g+d$ to which is assigned the value of 0.05 as in Mankiw et al. (1992).

\section{Exogenous economic policy variables:}

$\ln$ GovI - the log of the ratio of government (gross) fixed capital formation to GDP (both at market or current prices) is used as proxy for government investment.

$\ln G o v C$ - represents the log of government final consumption expenditure divided by GDP (both at market or current prices).

$\ln$ GovTx - log of the ratio of direct to indirect government tax revenues (both at market or current prices).

SdInfl - inflation volatility is measured by the standard deviation of the rate of growth in the consumer price index (CPI) computed as a centred three year moving average.

$\ln X / M$ - the log of the ratio of exports to imports (both at 2000 prices) is a proxy for gains from trade.

\section{Qualitative variables to control for the period of EU fiscal rules:}

$D 92 E U$ - dummy that takes value 1 for EU countries for the period 1992-2005 and 0 otherwise.

$D 97 E U$ - dummy that takes value 1 for EU countries for the period 1997-2005 and 0 otherwise.

$M g M$ - indicator for the margin of manoeuvre of fiscal policy, which is defined according to the SGP rules: before Maastricht it is assumed that EU countries have total margin of manoeuvre over fiscal policy $=>$ $M g M=1$; after Maastricht the margin of manoeuvre is computed as follows:

$$
\begin{aligned}
M g M & =(\mathrm{GBS}+3) / 3 & & \text { if GDP growth }>-0.75 \% \text { and }-3 \%<\mathrm{GBS}<0 \% \\
& =1 & & \text { if GDP growth }<-2 \% \text { or GBS }>0 \% ; \\
& =0.5 & & \text { if }-2 \%<\mathrm{GDP} \text { growth }<-0.75 \% \text { and GBS }<-3 \% ; \\
& =0.5 * 1+0.5 *(\mathrm{GBS}+3) / 3 & & \text { if }-2 \%<\mathrm{GDP}<-0.75 \% \text { and }-3 \%<\mathrm{GBS}<0 \% ; \\
& =0 & & \text { if growth GDP }>-0.75 \% \text { and GBS }<-3 \% ;
\end{aligned}
$$

GBS means government budget surplus and 0.5 is a plausible guess for the probability of the deficit not being considered 'excessive' by the European Commission in a situation of moderate recession. To simplify the analysis, this indicator is normalized to the interval [0;1]; 0 means no margin of manoeuvre and 1 means total margin of manoeuvre over fiscal policy.

Sources: OECD Statistical Compendium, April 2006 (for all variables except human capital). Data for human capital from 1970 to 1990 was interpolated from five-year observations from De la Fuente and Domenéch (2000). For the period 1996 to 2004 data were obtained from OECD Education at a Glance, various issues (1998 to 2006). Missing observations were filled by linear interpolation.

Notes: The panel of countries for which data were collected is the following:

EU countries: Austria, Belgium, Denmark, Finland, France, Germany, Greece, Ireland, Italy, Luxembourg, Netherlands, Portugal, Spain, Sweden, and the UK;

non-EU countries: Australia, Canada, Iceland, Japan, New Zealand, Norway, Switzerland, and the USA. 
Table 2. Results from dynamic fixed effects panel data estimations

\begin{tabular}{ccc|cc}
\hline Panel unit root tests & Level & $1^{\text {st }}$ diff. & \multicolumn{2}{|c}{ Pedroni panel cointegration tests } \\
\hline $\ln Y$ & -1.43 & -3.57 & Panel v -statistic & 4.54 \\
$\ln$ PrivI & -1.93 & -4.39 & Panel rho-statistic & 2.28 \\
$\ln H K$ & -0.38 & -3.58 & Panel pp-statistic & -2.69 \\
$\ln$ Pop & -2.34 & -4.88 & Panel ADF-statistic & -1.85 \\
$\ln$ GovI & -1.39 & -4.15 & Group rho-statistic & 3.67 \\
$\ln$ GovC & -1.80 & -4.05 & Group pp-statistic & -1.99 \\
$\ln$ GovTx & -1.71 & -4.29 & Group ADF-statistic & -0.71 \\
SDInfl & -3.32 & -5.56 & & \\
$\ln X / M$ & -1.92 & -4.22 & & \\
\hline
\end{tabular}

Notes: In the panel unit root tests the critical values for $1 \%, 5 \%$ and $10 \%$ are $-2.04,-1.90$, and -1.81 , respectively; for example, a $\mathrm{k}<-1.90$ implies rejection of the null hypothesis of unit root or non-stationarity at $5 \%$. Results and critical values for these tests were obtained by using the 'ipshin' command in STATA.

Pedroni tests were performed by using a procedure written by Peter Pedroni for RATS; all reported values for Pedroni statistics are distributed $\mathrm{N}(0,1)$ under the null hypothesis of no cointegration and those statistics are one-sided tests with a critical value of -1.64 for a level of significance of $5 \%$ ( $k<-1.64$ implies rejection of the null), except the $v$-statistic that has a critical value $1.64(\mathrm{k}>1.64$ means rejection of the null hypothesis). 
Table 3. Results from dynamic fixed effects panel data estimations

\begin{tabular}{|c|c|c|c|c|c|c|c|}
\hline & 1 & 2 & 3 & 4 & 5 & 6 & 7 \\
\hline $\begin{array}{l}\ln Y_{i t-1} \\
\text { Implied } \lambda \\
h w t c^{(a)}\end{array}$ & $\begin{array}{c}-0.0346 \\
(-2.99) * * * \\
{[0.035]} \\
19.7 \text { years }\end{array}$ & $\begin{array}{c}-0.0375 \\
(-3.33)^{* * *} \\
{[0.038]} \\
18.1 \text { years }\end{array}$ & $\begin{array}{c}-0.0350 \\
(-3.12)^{* * *} \\
{[0.036]} \\
19.4 \text { years }\end{array}$ & $\begin{array}{c}-0.0352 \\
(-4.53)^{* * *} \\
{[0.036]} \\
19.3 \text { years }\end{array}$ & $\begin{array}{c}-0.0590 \\
(-3.71)^{* * *} \\
{[0.061]} \\
11.4 \text { years }\end{array}$ & $\begin{array}{c}-0.0275 \\
(-2.06)^{* *} \\
{[0.028]} \\
24.9 \text { years }\end{array}$ & $\begin{array}{c}-0.0697 \\
(-4.39)^{* * *} \\
{[0.072]} \\
9.6 \text { years }\end{array}$ \\
\hline $\ln \operatorname{Priv}_{i t}$ & $\begin{array}{c}0.8103 \\
(2.57)^{* *}\end{array}$ & $\begin{array}{c}0.6537 \\
(2.40)^{* *}\end{array}$ & $\begin{array}{c}0.7960 \\
(2.60) * * *\end{array}$ & $\begin{array}{c}0.5073 \\
(2.31)^{* *}\end{array}$ & $\begin{array}{c}0.8021 \\
(2.19)^{* *}\end{array}$ & $\begin{array}{c}0.1897 \\
(0.41)\end{array}$ & $\begin{array}{c}0.4055 \\
(1.42)\end{array}$ \\
\hline $\ln H K_{i t}$ & $\begin{array}{c}1.662 \\
(3.85)^{* * *}\end{array}$ & $\begin{array}{c}1.1573 \\
(3.65)^{* * *}\end{array}$ & $\begin{array}{c}1.6359 \\
(5.22)^{* * *}\end{array}$ & $\begin{array}{c}1.1010 \\
(3.99) * * *\end{array}$ & $\begin{array}{c}1.1815 \\
(3.08) * * *\end{array}$ & $\begin{array}{c}0.4656 \\
(0.88)\end{array}$ & $\begin{array}{c}0.8096 \\
(2.54)^{* *}\end{array}$ \\
\hline $\ln$ Pop $_{i t}$ & $\begin{array}{c}-1.589 \\
(-2.35)^{* *}\end{array}$ & $\begin{array}{c}-1.4384 \\
(-2.56)^{* *}\end{array}$ & $\begin{array}{c}-1.5892 \\
(-2.46)^{* *}\end{array}$ & $\begin{array}{c}-1.7553 \\
(-3.86)^{* * *}\end{array}$ & $\begin{array}{c}-1.4018 \\
(-3.09)^{* * *}\end{array}$ & $\begin{array}{c}-0.2449 \\
(-0.41)\end{array}$ & $\begin{array}{c}-1.1757 \\
(-3.45) * * *\end{array}$ \\
\hline $\ln G o v I_{i t-I}$ & $\begin{array}{c}0.3694 \\
(2.19)^{* *}\end{array}$ & $\begin{array}{c}0.3616 \\
(2.40)^{* *}\end{array}$ & $\begin{array}{c}0.3550 \\
(2.21)^{* *}\end{array}$ & $\begin{array}{c}0.3203 \\
(2.66)^{* * *}\end{array}$ & $\begin{array}{c}0.1027 \\
(1.18)\end{array}$ & $\begin{array}{c}0.1935 \\
(0.91)\end{array}$ & $\begin{array}{l}0.1508 \\
(1.94)^{*}\end{array}$ \\
\hline $\ln G o v C_{i t-1}$ & $\begin{array}{c}-2.411 \\
(-2.80)^{* * *}\end{array}$ & $\begin{array}{c}-2.164 \\
(-3.06)^{* * *}\end{array}$ & $\begin{array}{c}-2.366 \\
(-2.97)^{* * *}\end{array}$ & $\begin{array}{c}-2.0996 \\
(-4.11)^{* * *}\end{array}$ & $\begin{array}{c}-0.9888 \\
(-2.65)^{* * *}\end{array}$ & $\begin{array}{c}-0.6251 \\
(-1.20)\end{array}$ & $\begin{array}{c}-0.9780 \\
(-3.17)^{* * *}\end{array}$ \\
\hline $\ln G o v T x_{i t-1}$ & $\begin{array}{c}0.1270 \\
(0.68)\end{array}$ & $\begin{array}{c}0.1137 \\
(0.67)\end{array}$ & $\begin{array}{c}0.1286 \\
(0.70)\end{array}$ & $\begin{array}{c}-0.0352 \\
(-0.26)\end{array}$ & $\begin{array}{c}-0.0193 \\
(-0.16)\end{array}$ & $\begin{array}{c}0.2387 \\
(1.08)\end{array}$ & $\begin{array}{c}0.0263 \\
(0.27)\end{array}$ \\
\hline$S d I n f l_{i t-1}$ & $\begin{array}{c}-0.0577 \\
(-1.97)^{* *}\end{array}$ & $\begin{array}{c}-0.0581 \\
(-2.18)^{* *}\end{array}$ & $\begin{array}{c}-0.0577 \\
(-2.01)^{* *}\end{array}$ & $\begin{array}{c}-0.0514 \\
(-2.33)^{* *}\end{array}$ & $\begin{array}{c}-0.0681 \\
(-1.99)^{* *}\end{array}$ & $\begin{array}{c}-0.0581 \\
(-0.36)\end{array}$ & $\begin{array}{c}-0.0658 \\
(-2.41)^{* *}\end{array}$ \\
\hline $\ln X / M_{i t-1}$ & $\begin{array}{c}0.8044 \\
(2.42)^{* *}\end{array}$ & $\begin{array}{c}0.7181 \\
(2.45)^{* *}\end{array}$ & $\begin{array}{c}0.7800 \\
(2.48)^{* *}\end{array}$ & $\begin{array}{c}0.5004 \\
(2.26)^{* *}\end{array}$ & $\begin{array}{c}0.4101 \\
(1.29)\end{array}$ & $\begin{array}{c}0.6157 \\
(1.45)\end{array}$ & $\begin{array}{c}0.1462 \\
(0.57)\end{array}$ \\
\hline$D 92 e u_{i t}$ & $\begin{array}{c}-0.0007 \\
(-0.25)\end{array}$ & & & & $\begin{array}{c}0.0039 \\
(0.61)\end{array}$ & & \\
\hline$D 97 e u_{i t}$ & & $\begin{array}{c}0.0054 \\
(2.22)^{* *}\end{array}$ & & $\begin{array}{c}0.0060 \\
(2.98) * * *\end{array}$ & & $\begin{array}{c}0.0112 \\
(1.97)^{* *}\end{array}$ & $\begin{array}{c}0.0093 \\
(3.72)^{* * *}\end{array}$ \\
\hline$M g M_{i t-l}$ & & & $\begin{array}{c}0.0012 \\
(0.52)\end{array}$ & & & & \\
\hline$\Delta \ln$ PrivI $_{i t}$ & $\begin{array}{c}0.1045 \\
(5.52)^{* * *}\end{array}$ & $\begin{array}{c}0.1047 \\
(5.59)^{* * *}\end{array}$ & $\begin{array}{c}0.1050 \\
(5.54)^{* * * *}\end{array}$ & $\begin{array}{c}0.1025 \\
(7.12)^{* * *}\end{array}$ & $\begin{array}{c}0.1106 \\
(4.42)^{* * * *}\end{array}$ & $\begin{array}{c}0.1171 \\
(3.77)^{* * *}\end{array}$ & $\begin{array}{c}0.1143 \\
(4.77)^{* * *}\end{array}$ \\
\hline$\Delta \ln H K_{i t}$ & $\begin{array}{c}-0.0509 \\
(-0.81)\end{array}$ & $\begin{array}{c}-0.0250 \\
(-0.40)\end{array}$ & $\begin{array}{c}-0.0541 \\
(-0.87)\end{array}$ & $\begin{array}{l}0.0264 \\
(0.49)\end{array}$ & $\begin{array}{c}-0.0784 \\
(-1.42)\end{array}$ & $\begin{array}{c}0.0005 \\
(0.01)\end{array}$ & $\begin{array}{c}-0.0668 \\
(-1.23)\end{array}$ \\
\hline$\Delta \ln$ Pop $_{i t}$ & $\begin{array}{c}0.0116 \\
(0.94)\end{array}$ & $\begin{array}{c}0.0104 \\
(0.83)\end{array}$ & $\begin{array}{l}0.0120 \\
(0.96)\end{array}$ & $\begin{array}{c}0.0099 \\
(1.00)\end{array}$ & $\begin{array}{l}0.0155 \\
(1.36)\end{array}$ & $\begin{array}{l}-0.0200 \\
(-1.85)^{*}\end{array}$ & $\begin{array}{l}0.0154 \\
(1.37)\end{array}$ \\
\hline$\Delta \ln$ GovI $_{i t}$ & $\begin{array}{c}0.0364 \\
(3.72)^{* * *}\end{array}$ & $\begin{array}{c}0.0372 \\
(3.81)^{* * *}\end{array}$ & $\begin{array}{c}0.0361 \\
(3.67)^{* * *}\end{array}$ & $\begin{array}{c}0.0354 \\
(4.28)^{* * *}\end{array}$ & $\begin{array}{c}0.0341 \\
(3.40)^{* * *}\end{array}$ & $\begin{array}{c}0.0357 \\
(2.68)^{* * *}\end{array}$ & $\begin{array}{c}0.0354 \\
(3.56)^{* * *}\end{array}$ \\
\hline$\Delta \ln G o v C_{i t}$ & $\begin{array}{c}-0.2585 \\
(-8.08) * * *\end{array}$ & $\begin{array}{c}-0.2593 \\
(-8.12)^{* * * *}\end{array}$ & $\begin{array}{c}-0.2586 \\
(-8.09)^{* * * *}\end{array}$ & $\begin{array}{c}-0.2618 \\
(-10.32)^{* * *}\end{array}$ & $\begin{array}{l}-0.1841 \\
(-5.27)^{* * *}\end{array}$ & $\begin{array}{c}-0.1904 \\
(-4.69)^{* * * *}\end{array}$ & $\begin{array}{c}-0.1850 \\
(-5.54) * * *\end{array}$ \\
\hline$\Delta \ln$ GovT $_{i t}$ & $\begin{array}{c}0.0258 \\
(2.20)^{* *}\end{array}$ & $\begin{array}{c}0.0252 \\
(2.14)^{* * *}\end{array}$ & $\begin{array}{c}0.0260 \\
(2.22)^{* *}\end{array}$ & $\begin{array}{l}0.0141 \\
(1.49)\end{array}$ & $\begin{array}{c}0.0145 \\
(1.37)\end{array}$ & $\begin{array}{c}0.0288 \\
(1.97)^{* *}\end{array}$ & $\begin{array}{c}0.0177 \\
(1.72)\end{array}$ \\
\hline$\Delta S d I n f l_{i t}$ & $\begin{array}{l}0.0001 \\
(0.11)\end{array}$ & $\begin{array}{l}-0.0001 \\
(-0.03)\end{array}$ & $\begin{array}{l}0.0001 \\
(0.10)\end{array}$ & $\begin{array}{c}-0.0003 \\
(-0.35)\end{array}$ & $\begin{array}{l}-0.0022 \\
(-1.12)\end{array}$ & $\begin{array}{c}0.0014 \\
(0.36)\end{array}$ & $\begin{array}{l}-0.0021 \\
(-1.09)\end{array}$ \\
\hline$\Delta \ln X / M_{i t}$ & $\begin{array}{c}-0.0118 \\
(-0.52) \\
\end{array}$ & $\begin{array}{c}-0.0139 \\
(-0.62) \\
\end{array}$ & $\begin{array}{r}-0.0117 \\
(-0.52) \\
\end{array}$ & $\begin{array}{c}-0.0154 \\
(-1.06) \\
\end{array}$ & $\begin{array}{c}0.0342 \\
(1.29)\end{array}$ & $\begin{array}{c}0.0500 \\
(1.40) \\
\end{array}$ & $\begin{array}{c}0.0286 \\
(1.13)\end{array}$ \\
\hline $\mathrm{R}^{2}$ & 0.5873 & 0.5913 & 0.5875 & 0.5634 & 0.5946 & 0.5030 & 0.6133 \\
\hline Time period & $1972-2004$ & $1972-2004$ & $1972-2004$ & $1972-2004$ & $1992-2004$ & $1997-2004$ & $1992-2004$ \\
\hline No. countries & 14 & 14 & 14 & 21 & 21 & 21 & 21 \\
\hline No. observ. & 448 & 448 & 448 & 641 & 273 & 168 & 273 \\
\hline
\end{tabular}

Sources: see Table 1.

Notes: $t$-statistics are in parentheses; significance level at which the null hypothesis is rejected: ***, 1\%; **, 5\%; and *, 10\%; the estimated speed of convergence to the steady-state $(\lambda-\ln (1-\phi))$ is in square brackets; models estimated controlling for fixed effects (see text for reasons why fixed effects make more sense than random effects in this context; Hausman tests also rejected random effects, nevertheless, equation in column 6 was estimated by random effects because the dummy $d 97 e u$ was dropped in the fixed effects estimation due to lack of variability).

In all estimations the presence of any pattern of heteroscedasticity and autocorrelation was controlled for by using robust standard errors. The long-run coefficients, their respective standard errors and $t$-statistics were estimated according to the relation $\theta_{s}=a_{s} / \phi_{i}$. Luxembourg and Iceland were excluded from the sample due to lack of observations for human capital.

(a) $h w t c$ means half way to convergence and measures the time it takes to go half way to the new steady-state output per capita or the time it takes to reduce half of the differences in output per capita among countries; $h w t c=\ln (0.5) / \ln (1-\phi)$. 
Table 4. Pooled mean group panel data estimations and robustness analysis

\begin{tabular}{|c|c|c|c|c|c|c|c|}
\hline & 1 & 2 & 3 & 4 & 5 & 6 & 7 \\
\hline $\begin{array}{l}\ln Y_{i t-1} \\
\text { Implied } \lambda \\
\text { hwtc }^{\text {(a) }}\end{array}$ & $\begin{array}{c}-0.0700 \\
(-6.72)^{* * *} \\
{[0.073]} \\
9.6 \text { years }\end{array}$ & $\begin{array}{c}-0.0643 \\
(-7.59)^{* * *} \\
{[0.066]} \\
10.4 \text { years }\end{array}$ & $\begin{array}{c}-0.0594 \\
(-7.87)^{* * *} \\
{[0.061]} \\
11.3 \text { years }\end{array}$ & $\begin{array}{c}-0.1726 \\
(-5.51)^{* * *} \\
{[0.1894]} \\
3.7 \text { years }\end{array}$ & $\begin{array}{c}-0.0377 \\
(-2.14)^{* *} \\
{[0.0384]} \\
18.0 \text { years }\end{array}$ & $\begin{array}{c}-0.0871 \\
(-3.28)^{* * *} \\
{[0.0911]} \\
7.6 \text { years }\end{array}$ & $\begin{array}{c}-0.0886 \\
(-1.35) \\
{[0.0928]} \\
7.5 \text { years }\end{array}$ \\
\hline $\ln$ PrivI $_{i t}$ & $\begin{array}{c}0.5451 \\
(4.21)^{* * *}\end{array}$ & $\begin{array}{c}0.3551 \\
(3.09)^{* * *}\end{array}$ & $\begin{array}{c}0.4937 \\
(3.87)^{* * *}\end{array}$ & $\begin{array}{c}0.4745 \\
(4.48)^{* * *}\end{array}$ & $\begin{array}{l}0.5679 \\
(1.67)^{*}\end{array}$ & $\begin{array}{c}1.1965 \\
(2.40)^{* *}\end{array}$ & $\begin{array}{c}0.2398 \\
(0.30)\end{array}$ \\
\hline $\ln H K_{i t}$ & $\begin{array}{c}1.2879 \\
(7.78)^{* * *}\end{array}$ & $\begin{array}{c}0.8142 \\
(3.89)^{* * *}\end{array}$ & $\begin{array}{c}1.4183 \\
(10.27)^{* * *}\end{array}$ & $\begin{array}{c}-0.0131 \\
(-0.07)\end{array}$ & $\begin{array}{l}0.8971 \\
(1.78)^{*}\end{array}$ & $\begin{array}{c}-0.7826 \\
(-0.96)\end{array}$ & $\begin{array}{l}2.3633 \\
(1.59)\end{array}$ \\
\hline $\ln P_{o p} p_{i t}$ & $\begin{array}{c}-0.9556 \\
(-5.28)^{* * *}\end{array}$ & $\begin{array}{c}-1.0070 \\
(-4.52)^{* * *}\end{array}$ & $\begin{array}{c}-0.9183 \\
(-3.99)^{* * *}\end{array}$ & $\begin{array}{c}-0.4429 \\
(-4.78) * * *\end{array}$ & $\begin{array}{l}-1.8416 \\
(-1.89)^{*}\end{array}$ & $\begin{array}{c}-0.5974 \\
(-2.31)^{* *}\end{array}$ & $\begin{array}{c}-1.4288 \\
(-1.10)\end{array}$ \\
\hline $\ln G o v I_{i t-1}$ & $\begin{array}{c}0.1770 \\
(3.14)^{* * * *}\end{array}$ & $\begin{array}{c}0.2672 \\
(3.01)^{* * *}\end{array}$ & $\begin{array}{c}0.2120 \\
(3.21)^{* * *}\end{array}$ & $\begin{array}{c}0.1089 \\
(3.21)^{* * *}\end{array}$ & $\begin{array}{c}0.2812 \\
(1.29)\end{array}$ & $\begin{array}{c}0.1041 \\
(0.83)\end{array}$ & $\begin{array}{c}0.0407 \\
(0.18)\end{array}$ \\
\hline $\ln G o v C_{i t-1}$ & $\begin{array}{c}-1.5428 \\
(-5.42)^{* * *}\end{array}$ & $\begin{array}{c}-1.5558 \\
(-4.36)^{* * *}\end{array}$ & $\begin{array}{c}-1.8797 \\
(-5.23)^{* * *}\end{array}$ & $\begin{array}{c}-0.3853 \\
(-2.42)^{* *}\end{array}$ & $\begin{array}{l}-1.9274 \\
(-1.75)^{*}\end{array}$ & $\begin{array}{c}-0.1352 \\
(-0.35)\end{array}$ & $\begin{array}{c}-1.6997 \\
(-1.15)\end{array}$ \\
\hline $\ln G o v T x_{i t-1}$ & $\begin{array}{r}0.0077 \\
(0.10)\end{array}$ & $\begin{array}{c}-0.0428 \\
(-0.43)\end{array}$ & $\begin{array}{l}0.0925 \\
(1.12)\end{array}$ & $\begin{array}{r}0.0187 \\
(0.42)\end{array}$ & $\begin{array}{c}-0.2074 \\
(-0.86)\end{array}$ & $\begin{array}{c}-0.0357 \\
(-0.22)\end{array}$ & $\begin{array}{c}-0.3744 \\
(-1.03)\end{array}$ \\
\hline$S d I n f l_{i t-I}$ & $\begin{array}{c}-0.0421 \\
(-3.48)^{* * *}\end{array}$ & $\begin{array}{c}-0.0547 \\
(-4.34)^{* * *}\end{array}$ & $\begin{array}{c}-0.0480 \\
(-3.48)^{* * *}\end{array}$ & $\begin{array}{c}-0.0131 \\
(-0.74)\end{array}$ & $\begin{array}{l}-0.0507 \\
(-1.63)\end{array}$ & $\begin{array}{c}-0.0358 \\
(-0.78)\end{array}$ & $\begin{array}{c}-0.0531 \\
(-0.68)\end{array}$ \\
\hline $\ln X / M_{i t-1}$ & $\begin{array}{c}0.1948 \\
(1.41) \\
\end{array}$ & $\begin{array}{c}0.4043 \\
(3.17) * * *\end{array}$ & $\begin{array}{c}0.3992 \\
(3.09)^{* * *}\end{array}$ & $\begin{array}{c}0.1634 \\
(1.51) \\
\end{array}$ & $\begin{array}{l}0.7463 \\
(1.73)^{*} \\
\end{array}$ & $\begin{array}{c}0.3146 \\
(0.78) \\
0\end{array}$ & $\begin{array}{r}0.3369 \\
(0.70) \\
\end{array}$ \\
\hline$D 92 e u_{i t}$ & $\begin{array}{c}-0.0010 \\
(0.29)\end{array}$ & & & & & & \\
\hline$D 97 e u_{i t}$ & & $\begin{array}{c}0.0087 \\
(4.06) * * *\end{array}$ & & $\begin{array}{c}0.0101 \\
(5.38)^{* * *}\end{array}$ & & & \\
\hline$M g M_{i t-1}$ & & & $\begin{array}{c}0.0012 \\
(0.42) \\
\end{array}$ & & & & \\
\hline $\begin{array}{l}\mathrm{R}^{2} \\
\text { Log-likelihood }\end{array}$ & 1472.3 & 1469.9 & 1464.2 & & 0.5953 & 0.7355 & 0.6172 \\
\hline Time period & $\begin{array}{c}1972-2004 \\
14\end{array}$ & $\begin{array}{c}1972-2004 \\
14\end{array}$ & 1972-2004 & 1997-2004 & 1972-1996 & 1997-2004 & $\begin{array}{c}1997-2004 \\
7\end{array}$ \\
\hline $\begin{array}{l}\text { No. countries } \\
\text { No. observ. }\end{array}$ & $\begin{array}{c}14 \\
448\end{array}$ & $\begin{array}{c}14 \\
448\end{array}$ & $\begin{array}{c}14 \\
448\end{array}$ & $\begin{array}{c}21 \\
168\end{array}$ & & $\begin{array}{c}14 \\
112\end{array}$ & \\
\hline $\ln g d p p c_{i t-1}^{(\mathrm{b})}$ & & & & $\begin{array}{c}-0.1946 \\
(-2.40) * *\end{array}$ & $\begin{array}{l}-0.0593 \\
(-2.32)^{* *}\end{array}$ & $\begin{array}{c}-0.0611 \\
(-2.70) * * *\end{array}$ & $\begin{array}{l}-0.0592 \\
(-1.71)^{*}\end{array}$ \\
\hline$d 92 e u_{i t}{ }^{(\mathrm{b})}$ & & & & $\begin{array}{c}0.0068 \\
(0.87)\end{array}$ & & & \\
\hline $\begin{array}{l}\text { Time period } \\
\text { No. observations } \\
\end{array}$ & & & & $\begin{array}{c}1992-2004 \\
252 \\
\end{array}$ & $\begin{array}{c}1972-1991 \\
266 \\
\end{array}$ & $\begin{array}{c}1992-2004 \\
182\end{array}$ & $\begin{array}{c}1992-2004 \\
91\end{array}$ \\
\hline
\end{tabular}

Sources: See Table 1.

Notes: All equations were estimated including short-run dynamics and a constant, but due to space limitations only longrun and dummy coefficients are reported; in fact, more attention is given to the long-run coefficients because short-run dynamics are just used to control for annual or cyclical fluctuations in output per capita. PMG estimations are presented in columns 1, 2 and 3; Arellano-Bond techniques are used to estimate model 4; and a fixed effects estimator is used to estimate models in columns 5, 6 and 7. Robust standard errors are used to control for the presence of heteroscedasticity. $t$-statistics are in parentheses ( $z$-statistics for the PMG and Arellano-Bond estimations); significance level at which the null hypothesis is rejected: ***, $1 \%$;*, $5 \%$; and *, 10\%; again, the speed of convergence $(\lambda)$ is in square brackets. Luxembourg and Iceland were excluded from the sample due to lack of observations for human capital.

(a) See Table 3.

(b) In these lines the convergence coefficient and the coefficient on the dummy $d 92 e u$ (when included in the model, instead of $d 97 \mathrm{eu}$ ) are presented and result from a similar specification to the one above but using another time period or threshold; the coefficients on the other exogenous variables are not reported but are available upon request. 
Table 5. Results from five-year time spans estimations

\begin{tabular}{|c|c|c|c|c|c|c|}
\hline & (1) FE & (2) FE & (3) DIF-GMM & (4) SYS-GMM & (5) SYS-GMM & (6) $2 \mathrm{SLS}$ \\
\hline $\begin{array}{l}\ln Y_{i t-5} \\
\text { Implied } \lambda \\
\text { hwtc }\end{array}$ & $\begin{array}{c}-0.3427 \\
(-5.44)^{* * *} \\
{[0.084]} \\
8.3 \text { years }\end{array}$ & $\begin{array}{c}-0.3272 \\
(-5.15)^{* * *} \\
{[0.079]} \\
8.7 \text { years }\end{array}$ & $\begin{array}{c}-0.5334 \\
(-4.57)^{* * *} \\
{[0.152]} \\
4.5 \text { years }\end{array}$ & $\begin{array}{c}-0.3802 \\
(-3.10) * * * \\
{[0.096]} \\
7.2 \text { years }\end{array}$ & $\begin{array}{c}-0.3123 \\
(-2.96)^{* * *} \\
{[0.075]} \\
9.3 \text { years }\end{array}$ & $\begin{array}{c}-0.2825 \\
(-3.67)^{* * *} \\
{[0.066]} \\
10.4 \text { years }\end{array}$ \\
\hline $\ln$ PrivI $_{i t}$ & $\begin{array}{c}0.1935 \\
(2.91)^{* * *}\end{array}$ & $\begin{array}{c}0.1972 \\
(3.08) * * *\end{array}$ & $\begin{array}{c}0.1204 \\
(1.10)\end{array}$ & $\begin{array}{c}0.1217 \\
(2.14)^{* *}\end{array}$ & $\begin{array}{c}0.1028 \\
(3.10)^{* * *}\end{array}$ & $\begin{array}{l}0.0859 \\
(1.94)^{*}\end{array}$ \\
\hline $\ln H K_{i t}$ & $\begin{array}{c}0.3989 \\
(3.61)^{* * *}\end{array}$ & $\begin{array}{c}0.4586 \\
(6.94)^{* * *}\end{array}$ & $\begin{array}{c}0.6555 \\
(3.13)^{* * *}\end{array}$ & $\begin{array}{c}0.3094 \\
(2.88)^{* *}\end{array}$ & $\begin{array}{c}0.2658 \\
(2.31)^{* *}\end{array}$ & $\begin{array}{c}0.2400 \\
(3.01)^{* * *}\end{array}$ \\
\hline $\ln P o p_{i t}$ & $\begin{array}{c}-0.2443 \\
(-4.19) * * *\end{array}$ & $\begin{array}{c}-0.2822 \\
(-5.32)^{* * *}\end{array}$ & $\begin{array}{c}-0.2363 \\
(-4.76)^{* * *}\end{array}$ & $\begin{array}{c}-0.2436 \\
(-5.71)^{* * *}\end{array}$ & $\begin{array}{c}-0.2296 \\
(-4.07)^{* * *}\end{array}$ & $\begin{array}{c}-0.2212 \\
(-2.73)^{* * * *}\end{array}$ \\
\hline $\ln G o v I_{i t}$ & $\begin{array}{c}0.0126 \\
(0.63)\end{array}$ & $\begin{array}{c}0.0062 \\
(0.31)\end{array}$ & $\begin{array}{c}-0.0290 \\
(-2.19) * *\end{array}$ & $\begin{array}{c}0.0240 \\
(1.21)\end{array}$ & & $\begin{array}{c}0.0462 \\
(2.10)^{* *}\end{array}$ \\
\hline $\ln G o v C_{i t}$ & $\begin{array}{c}-0.3309 \\
(-3.81)^{* * *}\end{array}$ & $\begin{array}{c}-0.3429 \\
(-4.08)^{* * *}\end{array}$ & $\begin{array}{c}-0.3239 \\
(-3.45)^{* * *}\end{array}$ & $\begin{array}{c}-0.0880 \\
(-0.82)\end{array}$ & & $\begin{array}{l}0.1083 \\
(-1.52)\end{array}$ \\
\hline $\ln G o v T x_{i t}$ & $\begin{array}{c}0.0750 \\
(2.25)^{* *}\end{array}$ & $\begin{array}{c}0.0769 \\
(2.33)^{* *}\end{array}$ & $\begin{array}{c}0.0874 \\
(1.57)\end{array}$ & $\begin{array}{c}-0.0282 \\
(-0.81)\end{array}$ & & $\begin{array}{c}0.0365 \\
(1.42)\end{array}$ \\
\hline$S_{d I n f l}{ }_{i t}$ & $\begin{array}{c}-0.0110 \\
(-1.17)\end{array}$ & $\begin{array}{c}-0.0112 \\
(-1.26)\end{array}$ & $\begin{array}{c}-0.0111 \\
(-1.36)\end{array}$ & $\begin{array}{c}-0.0100 \\
(-1.02)\end{array}$ & & $\begin{array}{c}-0.0108 \\
(-0.98)\end{array}$ \\
\hline $\ln X / M_{i t}$ & $\begin{array}{c}0.1587 \\
(2.19)^{* *}\end{array}$ & $\begin{array}{l}0.1362 \\
(1.84 *)\end{array}$ & $\begin{array}{c}0.0648 \\
(0.64)\end{array}$ & $\begin{array}{l}0.1689 \\
(2.06)^{*}\end{array}$ & & $\begin{array}{l}0.1511 \\
(1.83)^{*}\end{array}$ \\
\hline D96eu $u_{i t}$ & $\begin{array}{c}0.0151 \\
(0.84)\end{array}$ & & $\begin{array}{c}0.0149 \\
(1.07)\end{array}$ & $\begin{array}{c}0.0432 \\
(3.47)^{* * *}\end{array}$ & $\begin{array}{c}0.0444 \\
(2.59)^{* *}\end{array}$ & $\begin{array}{c}0.0369 \\
(2.05)^{* *}\end{array}$ \\
\hline$M g M_{i t}$ & & $\begin{array}{c}0.0294 \\
(1.21)\end{array}$ & & & & \\
\hline $\begin{array}{l}\mathrm{R}^{2} \\
\text { Hansen test }\end{array}$ & 0.6115 & 0.6162 & 0.74 & 0.90 & 0.63 & 0.4418 \\
\hline 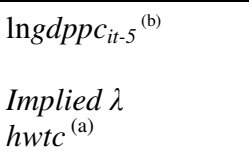 & $\begin{array}{c}-0.3251 \\
(-4.96) * * * \\
{[0.079]} \\
8.8 \text { years }\end{array}$ & & $\begin{array}{c}-0.4606 \\
(-4.52)^{* * * *} \\
{[0.123]} \\
5.6 \text { years }\end{array}$ & $\begin{array}{c}-0.2866 \\
(-1.76)^{*} \\
{[0.068]} \\
10.3 \text { years }\end{array}$ & $\begin{array}{c}-0.2322 \\
(-1.81)^{*} \\
{[0.053]} \\
13.1 \text { years }\end{array}$ & $\begin{array}{c}-0.2303 \\
(-3.13)^{* * *} \\
{[0.052]} \\
13.2 \text { years }\end{array}$ \\
\hline$d 91 e u_{i t}{ }^{(\mathrm{b})}$ & $\begin{array}{c}-0.0141 \\
(-0.91) \\
\end{array}$ & & $\begin{array}{l}-0.0217 \\
(-1.79)^{*}\end{array}$ & $\begin{array}{l}0.0059 \\
(0.33)\end{array}$ & $\begin{array}{c}0.0070 \\
(0.49)\end{array}$ & $\begin{array}{c}-0.0010 \\
(-0.05)\end{array}$ \\
\hline $\begin{array}{l}\mathrm{R}^{2} \\
\text { Hansen test }\end{array}$ & 0.6114 & & 0.70 & 0.92 & 0.65 & 0.3986 \\
\hline $\begin{array}{l}\text { No. countries } \\
\text { No. time periods } \\
\text { No. observations }\end{array}$ & $\begin{array}{c}14 \\
7 \\
98\end{array}$ & $\begin{array}{c}14 \\
7 \\
98\end{array}$ & $\begin{array}{c}14 \\
6 \\
84\end{array}$ & $\begin{array}{c}14 \\
7 \\
98\end{array}$ & $\begin{array}{c}14 \\
7 \\
98\end{array}$ & $\begin{array}{c}14 \\
6 \\
84\end{array}$ \\
\hline
\end{tabular}

\section{Sources: See Table 1.}

Notes: $t$-statistics are in parentheses; significance level at which the null hypothesis is rejected: ***, $1 \%$; **, $5 \%$; and *, $10 \%$; the estimated speed of convergence to the steady-state $(\lambda=[-\ln (1-\phi)] / 5)$ is in square brackets. In columns 1 and 2 the model is estimated controlling for fixed effects. The instruments used for DIF-GMM are the second and third lags of the log of output per capita; all other right-hand-side variables are assumed exogenous and are instrumented with their own values; the additional instrument used in the SYS-GMM is the difference of the log of output per capita lagged one period. A two-stages least squares estimator is used to obtain the results presented in the column 7 (here the $\log$ of initial output per capita is instrumented with its second lag). The presence of any pattern of heteroscedasticity and autocorrelation is controlled for by using robust standard errors. The values reported for the Hansen test are the $p$ values for the null hypothesis of a valid specification. Luxembourg was excluded from the sample due to lack of observations for human capital.

(a) See Table 3.

(b) These results come from a similar specification to the one reported above in the same column but including the variable d91eu instead of $d 96 \mathrm{eu}$; the coefficients on the other variables are not reported but are available upon request. 